NBER WORKING PAPER SERIES

\title{
THE GROWTH IN SOCIAL SECURITY BENEFITS AMONG THE RETIREMENT AGE POPULATION FROM INCREASES IN THE CAP ON COVERED EARNINGS
}

\author{
Alan L. Gustman \\ Thomas Steinmeier \\ Nahid Tabatabai \\ Working Paper 16501 \\ http://www.nber.org/papers/w16501
}

NATIONAL BUREAU OF ECONOMIC RESEARCH

1050 Massachusetts Avenue

Cambridge, MA 02138

October 2010

This research was supported by a grant from the U.S. Social Security Administration (SSA) through the Michigan Retirement Research Center (MRRC) under grant number UM10-21. The findings and conclusions expressed are solely those of the authors and do not represent the views of the NBER, SSA or the MRRC. David Olson of the Social Security Administration was extremely helpful to us in dealing with the ANYPIA program.

NBER working papers are circulated for discussion and comment purposes. They have not been peerreviewed or been subject to the review by the NBER Board of Directors that accompanies official NBER publications.

(C) 2010 by Alan L. Gustman, Thomas Steinmeier, and Nahid Tabatabai. All rights reserved. Short sections of text, not to exceed two paragraphs, may be quoted without explicit permission provided that full credit, including $(\mathcal{C}$ notice, is given to the source. 
The Growth in Social Security Benefits Among the Retirement Age Population from Increases in the Cap on Covered Earnings

Alan L. Gustman, Thomas Steinmeier, and Nahid Tabatabai

NBER Working Paper No. 16501

October 2010

JEL No. D31,H23,H55,J14,J26

\begin{abstract}
This paper investigates how increases in the level of maximum earnings subject to the Social Security payroll tax have affected Social Security benefits and taxes. The analysis uses data from the Health and Retirement Study to ask how different the present value of own benefits and taxes would be for the cohort born from 1948 to 1953 (ages 51 to 56 in 2004) if they faced the lower cap on the payroll tax that faced those born twelve and twenty four years earlier, but otherwise had the same earnings stream and faced the same benefit formula. We find that for those in the Early Boomer cohort of the Health and Retirement Study, ages 51 to 56 in 2004, that after adjusting for nominal wage growth, benefits were increased by 1.5 percent by the increase in the payroll tax ceiling compared to the cohort twelve years older, and by 3.7 percent over the benefits under the payroll tax ceiling for the cohort twenty four years older. Tax receipts were increased by 5.3 and 10.7 percent over tax receipts that would have been collected under the tax ceilings that applied to the cohorts 12 and 24 years older respectively. About 25 percent of the additional tax revenues created by the increase in the payroll tax cap between the Early Boomer cohort and those twelve years older was diverted to increased benefits. Similarly, about 31 percent of the additional tax revenues created by the increase in the payroll tax cap between the Early Boomer cohort and those twenty four years older took the form of increased benefits. Results are also presented separately for men and women, for those in the top quartile of earners, and for those at the tax ceiling throughout their work lives.
\end{abstract}

Alan L. Gustman

Department of Economics

Dartmouth College

Hanover, NH 03755-3514

and NBER

ALAN.L.GUSTMAN@DARTMOUTH.EDU
Nahid Tabatabai

Department of Economics

Dartmouth College

Hanover, N.H. 03755

Nahid.Tabatabai@dartmouth.edu

Thomas Steinmeier

Department of Economics

Texas Tech University

Lubbock, TX 79409

thomas.steinmeier@ttu.edu 
When considering how to narrow the funding gap facing Social Security, policy makers continue to consider the option of raising the maximum salary subject to the payroll tax (U.S. Senate, Special Committee on Aging, 2010). In this paper we attempt to improve our understanding of how changes in the maximum level of earnings subject to the payroll tax have affected Social Security taxes and benefits. We use data from the Health and Retirement Study to separate the changes in taxes and benefits resulting from changes in the cap on income subject to payroll taxes from the effects of other complex changes that have occurred contemporaneously with the rise in the cap. Our strategy is to ask what benefits and taxes would have been for members of the HRS cohort ages 51 to 56 in 2004 if they faced the same maximum income subject to the payroll tax that applied to members of cohorts who were twelve and twenty four years older.

An increase in maximum covered earnings has an immediate effect on payroll tax revenues. But unlike an across the board increase in the payroll tax rate, an increase in maximum covered earnings restricts the tax increase to those with highest earnings. It has no effect on many workers, raising tax costs only for those with earnings above the old cap.

In addition, as opposed to an increase in the payroll tax rate, raising the tax ceiling creates a leak in the (future) finances of the system in the form of an increase in future benefit obligations to be paid to those at the top of the earnings distribution. Those who have earnings above the old cap have more of their total lifetime earnings covered by Social Security when the cap is increased. As a result, they are entitled to higher benefits. Although one could increase the cap on covered earnings without raising Social Security benefits, some are loathe to do this because it violates the insurance principle underlying Social Security. In keeping with the redistributive motivation of Social Security, for those at the cap benefits rise by only fifteen 
percent of the increase in covered earnings.

From 1951 through 2004, maximum taxable earnings increased from $\$ 3,600$ to $\$ 87,900$, an increase of 24.4 times. Over the same period average annual covered earnings increased from $\$ 2,799$ to $\$ 35,649$, an increase of 12.7 times. $^{2}$ Thus the rate of increase in maximum taxable earnings has been about twice the rate of increase of average earnings

Our empirical analysis takes as an earnings baseline the covered earnings for the youngest cohort thus far included in the data released by the Health and Retirement Study (HRS), the Early Boomer Cohort. ${ }^{3}$ We use these data to study how increases in maximum taxable earnings have affected the benefits of members of this cohort relative to members of cohorts that are twelve and twenty four years older. We estimate how the benefits of the younger cohort would have changed had they faced the lower ceiling on taxable earnings that faced members of the original HRS cohort, who are twelve years older, and the ceiling for the CODA (Children of the Depression) cohort, who are twelve years older than that. ${ }^{4}$ In making our calculations, all we change is the ceiling on earnings subject the payroll tax that was in place

${ }^{2}$ There is a small element of simultaneity here as part of the increase in average covered earnings is the result of the increase in the earnings cap.

${ }^{3}$ The HRS survey was in the field as of the writing of this paper. It is now collecting data for a new cohort, the Mid Boomers, who are ages 51 to 56 in 2010.

${ }^{4}$ In calculating benefits we hold earnings history constant at the level observed for the Early Boomer cohort, and use the benefit formula in place in 2004. Benefits for the Early Boomer cohort are based on Average Indexed Monthly Earnings (AIME), computed from covered earnings, increased by a wage index up to the year the individual turns age 60 . The AIME is averaged over the highest 35 years of covered, indexed earnings. Earnings after age 60 will enter into the AIME calculation if they exceed indexed earnings in the lowest of the 35 years previously counted toward the AIME. From Average Indexed Covered (Monthly) Earnings, the Primary Insurance Amount (PIA) is calculated. For a person turning age 60 in 2004, the PIA replaced 90 percent of the first $\$ 612$ in monthly earnings, 32 percent of the next $\$ 3,077$, and 15 percent of the amount above $\$ 3,689$. This same formula is applied to the same earnings history for each member of the HRS cohort, but the level of maximum covered earnings is changed when the simulation pertains to those born twelve and twenty four years earlier. 
when the person was of a particular age. Otherwise we risk confounding our findings with the effects of other contemporaneous changes that have also affected benefits. For example, members of the Early Boomer cohort had a higher normal retirement age than did members of the HRS cohort. At least in this respect, the benefit formula applicable to the HRS cohort was more generous than the benefit formula for Early Boomers.

Our analysis utilizes Social Security earnings records for those HRS respondents who gave explicit permission to allow their earnings records to be matched to the basic survey instrument, while imputing benefits for those without a matched earnings record. ${ }^{5}$ Social Security benefits are calculated from data on yearly covered earnings using the Social Security Administration's ANYPIA program. In analyzing the effect of changes in the Social Security earnings cap, we ask how benefits would have changed (for the cohort of Early Boomers, those ages 51 to 56 in 2004) if the maximum taxable earnings that applied to the HRS cohort of 51 to 56 year olds instead had applied to the Early Boomer cohort. To simulate the effects of a lower ceiling on covered earnings for members of older cohorts, while holding all other factors constant, we artificially truncate the level of (real) earnings inserted into the ANYPIA program by the earnings cap that applied twelve or twenty four years earlier, adjusting for differences in average earnings over the period. Using this methodology, we simulate the effects of the increase in the payroll tax ceiling as experienced between the cohorts aged 51 to 56 in 2004 and in 1992 and between those 51 to 56 in 2004 vs. 1980 .

${ }^{5}$ In the past two years, Social Security benefits have provided an important buffer to the decline in the stock market. In part because of the dominating presence of Social Security, the recent decline in the stock market reduced total retirement wealth by about 5 percentage points for the population approaching retirement age (Gustman, Steinmeier and Tabatabai, 2010). The cushion provided by Social Security is especially important for those in the lower half of the income and wealth distributions, the usual targets of social policy. But those in the lower half of the earnings distribution are largely unaffected by the increase in the ceiling on taxable earnings. 
To determine how changes in the earnings cap have affected the distribution of benefits, and in particular how these changes have affected those in the top of the earnings distribution, we examine the changes in benefits for those falling in different earnings quartiles, focusing a good deal of our attention on those falling in the highest earnings quartile.

Section II of the paper discusses the cap on earnings subject to the payroll tax and describes more fully how that cap has changed over time. Section III uses HRS data for the Early Boomer cohort to summarize changes in monthly Social Security benefits due to the change in the maximum level of covered earnings between the Early Boomer cohort and those in a cohort 12 years older, and then compared to a cohort 24 years older. In Section IV we examine the effects on both benefits and taxes of increases in the ceiling on taxable earnings for those with earnings at or above the earnings cap throughout their lifetimes. Section V uses HRS data to investigate the effects of changes in the earnings cap on the present values of benefits and taxes over the lifetime of members of the Early Boomer cohort, while Section VI discusses the implications of our findings.

\section{Maximum taxable earnings subject to the payroll tax}

From 1937 to 1949 , annual maximum earnings subject to the payroll tax was $\$ 3,000$. Once the real value of the $\$ 3,000$ cap was eroded by rising earnings, the share of total earnings covered by Social Security began to decline, and continued down for decades. A reversal in policy was implemented in the mid 1970s and the cap climbed relative to average earnings, before stabilizing in the 1980s.

To illustrate the effects of changes in the earnings cap, suppose first we are dealing with a member of the original HRS cohort who was 56 in 1992 and who worked on a long term job until age 60 in 1996. For simplicity, this individual's yearly earnings always increased over his 
lifetime, and earnings from 1961 are the lowest of his annual earnings counted when computing AIME (Average Indexed Monthly Earnings). In 1961, the cap on yearly earnings subject to the payroll tax was $\$ 4,800$, about 17 percent greater than average annual earnings in private employment for that year. Roughly speaking, any earnings above average earnings were not subject to the payroll tax and would not generate future benefits. Now consider a person who was 56 in 2004, leaving a long term job in 2008 at age 60, with earnings from 1973 the lowest earnings counting toward AIME. In 1973, earnings up to $\$ 10,800$ were covered by Social Security and subject to a payroll tax. Since earnings in the private sector averaged about $\$ 7,580$, earnings up to 42 percent above the average level were taxed and generated benefits. Of course, many of those with relatively low earnings were not affected by the increase in maximum covered earnings, but many with moderate or high earnings found their AIME increased by the application of a higher ceiling.

Any change in the earnings cap over time should be adjusted for changes in average earnings over time. To make that adjustment, we use the calculated wage growth used to index for earnings growth in the AIME calculation. Members of the Early Boomer cohort, born from 1948 to 1953, would have reached age 25 between 1973 and 1978. Members of the original HRS cohort, born from 1936 to 1941, reached age 25 between 1961 and 1966. After indexing, $\$ 4,800$, the earnings cap for those age 25 in 1961 , amounts to $\$ 8,880$ twelve years later. ${ }^{6}$ Thus over the twelve year period from 1961 to 1973, the real cap on earnings increased by 21.6 percent

\footnotetext{
${ }^{6}$ As noted above, the cap on covered earnings does have an effect on average covered earnings. When the cap is increased, that raises average earnings. Thus the simple adjustment for indexing used here overstates the adjustment that should be applied to the cap in earnings from the earlier year. Of course, most of the increase in average earnings is due to the increase in wages observed as a result of productivity growth, changes in the underlying wage structure and inflation, with modification due to the changing mix in employment in favor of more women, whose wages still fall below those of men.
} 
$(10,800 / 8,880)$. Similarly, adjusting the $\$ 6,600$ cap on earnings in 1966 by the index applicable over the next twelve years increases the real cap to $\$ 14,124$. Comparing the actual ceiling in 1978 with the ceiling from 1966 after adjusting by the wage index, the cap on maximum covered earnings is 25.3 percent $(17,700 / 14,124)$ higher in 1978 than in 1966 . Thus the real earnings cap is higher for members of younger cohorts.

Now consider in more detail how the cap on taxable earnings has changed over time relative to the average annual wage covered by Social Security. Table 1 reports these data for the period 1951 through 2004. As can be seen, over time policy makers have increased maximum covered earnings more rapidly than the increase in average earnings. For the decades of the 1950s and 1960s, the maximum level of earnings subject to the payroll tax was a bit greater than the average wage. ${ }^{7}$ The ratios of maximum taxable earnings to average annual wages ranged between 1.0 and 1.4. It was in the early and mid 1970s that the cap on taxable earnings began to rise much more rapidly than the average wage. By 1983, the ratio of maximum earnings to average covered wage roughly stabilized, and has since varied between 2.3 and 2.55.

Roughly speaking, if members of the Early Boomer cohort, ages 51 to 56 in 2004, had earnings between ages 25 and 60 count as their high 35 years of earnings, for those in the middle of this cohort, covered earnings between 1975 and 2010 would count toward their AIME. Thus for this cohort, counted earnings would not include earnings from the period with a very low cap, where the ratio of the cap to average earnings was between 1 and 1.5. Almost all the earnings counted in determining their AIME would have been within periods after 1983, when there was a high cap on covered earnings and a ratio of the cap to average earnings of 2.3 to 2.55 . (We treat

\footnotetext{
${ }^{7}$ In the early years of Social Security, maximum taxable earnings exceeded the earnings of almost all workers. Ninety seven percent of all workers in 1937 and 1940 had earnings below the taxable maximum. By 1945, 86 percent of workers had earnings below the maximum. (Source: Social Security Bulletin, 2007, Table 4.B4)
} 
the period after 2004 as if the relation between the earnings cap and average earnings remains within this range.)

For those ages 51 to 56 in 1992, included as part of the original HRS cohort, earnings from roughly 1963 to 1998 count in determining their AIME. Compared to the Early Boomer cohort, that adds in a period of twelve years from 1963 to 1975. During this period, the earnings cap was low, with a ratio of the earnings cap to average earnings ranging from 1.03 to 1.64 . At the same time, compared to the Early Boomer cohort, earnings over a period of twelve years from 1998 to 2010 would no longer count. During this period, the ratio of the cap to average earnings was high, ranging from 2.37 to 2.55 .

The difference in the earnings cap between those members of the Early Boomer cohort who were 51 to 56 in 2004, and those members of the CODA (Children of the Depression) Cohort who were 51 to 56 in 1980, is even wider. Consider members of the CODA cohort born from 1924 to 1929 , ages 51 to 56 in 1980 . Earnings in 1951 would be the earliest earnings to be included in their AIME calculation. From 1951 to 1963, the ratio of maximum covered earnings to the average wage ranges from 1.09 to 1.29 . Making an incremental comparison with members of the HRS cohort, removing the period from 1986 to 1998, the last years counted in determining the AIME for member of the HRS cohort, eliminates a twelve year period where the ratio of the cap on covered earnings ranged from 2.33 to 2.55 . 
Table 1: Maximum Taxable Earnings and Average Annual Wage

\begin{tabular}{|c|c|c|c|c|c|c|c|}
\hline Year & $\begin{array}{l}\text { Maximum } \\
\text { Taxable } \\
\text { Earnings }\end{array}$ & $\begin{array}{l}\text { Average } \\
\text { Annual } \\
\text { Wage }\end{array}$ & $\begin{array}{l}\text { Maximum } \\
\text { Earnings/Average } \\
\text { Wage }\end{array}$ & Year & $\begin{array}{l}\text { Maximum } \\
\text { Taxable } \\
\text { Earnings }\end{array}$ & $\begin{array}{l}\text { Average } \\
\text { Annual } \\
\text { Wage }\end{array}$ & $\begin{array}{l}\text { Maximum } \\
\text { Earnings/Average } \\
\text { Wage }\end{array}$ \\
\hline 1951 & 3600 & 2799 & 1.29 & 1978 & 17700 & 10556 & 1.68 \\
\hline 1952 & 3600 & 2973 & 1.21 & 1979 & 22900 & 11479 & 1.99 \\
\hline 1953 & 3600 & 3139 & 1.15 & 1980 & 25900 & 12513 & 2.07 \\
\hline 1954 & 3600 & 3156 & 1.14 & 1981 & 29700 & 13773 & 2.16 \\
\hline 1955 & 4200 & 3301 & 1.27 & 1982 & 32400 & 14531 & 2.23 \\
\hline 1956 & 4200 & 3532 & 1.19 & 1983 & 35700 & 15239 & 2.34 \\
\hline 1957 & 4200 & 3642 & 1.15 & 1984 & 37800 & 16135 & 2.34 \\
\hline 1958 & 4200 & 3674 & 1.14 & 1985 & 39600 & 16823 & 2.35 \\
\hline 1959 & 4800 & 3856 & 1.24 & 1986 & 42000 & 17322 & 2.42 \\
\hline 1960 & 4800 & 4007 & 1.20 & 1987 & 43800 & 18427 & 2.38 \\
\hline 1961 & 4800 & 4087 & 1.17 & 1988 & 45000 & 19334 & 2.33 \\
\hline 1962 & 4800 & 4291 & 1.12 & 1989 & 48000 & 20100 & 2.39 \\
\hline 1963 & 4800 & 4397 & 1.09 & 1990 & 51300 & 21028 & 2.44 \\
\hline 1964 & 4800 & 4576 & 1.05 & 1991 & 53400 & 21812 & 2.45 \\
\hline 1965 & 4800 & 4659 & 1.03 & 1992 & 55500 & 22935 & 2.42 \\
\hline 1966 & 6600 & 4938 & 1.34 & 1993 & 57600 & 23133 & 2.49 \\
\hline 1967 & 6600 & 5213 & 1.27 & 1994 & 60600 & 23754 & 2.55 \\
\hline 1968 & 7800 & 5572 & 1.40 & 1995 & 61200 & 24706 & 2.48 \\
\hline 1969 & 7800 & 5894 & 1.32 & 1996 & 62700 & 25914 & 2.42 \\
\hline 1970 & 7800 & 6186 & 1.26 & 1997 & 65400 & 27426 & 2.38 \\
\hline 1971 & 7800 & 6497 & 1.20 & 1998 & 68400 & 28861 & 2.37 \\
\hline 1972 & 9000 & 7134 & 1.26 & 1999 & 72600 & 30470 & 2.38 \\
\hline 1973 & 10800 & 7580 & 1.42 & 2000 & 76200 & 32155 & 2.37 \\
\hline 1974 & 13200 & 8031 & 1.64 & 2001 & 80400 & 32922 & 2.44 \\
\hline 1975 & 14100 & 8631 & 1.63 & 2002 & 84900 & 33252 & 2.55 \\
\hline 1976 & 15300 & 9226 & 1.66 & 2003 & 87000 & 34065 & 2.55 \\
\hline 1977 & 16500 & 9779 & 1.69 & 2004 & 87900 & 35649 & 2.47 \\
\hline
\end{tabular}

Source: Social Security Bulletin (2007) Table 2.A8. From 1937 to 1950, maximum taxable earnings was $\$ 3000$. 
Table 2: Percentage of Workers with Earnings Below Annual Maximum Taxable

\begin{tabular}{|c|c|c|c|c|c|c|c|}
\hline Year & \multicolumn{3}{|c|}{ All Workers } & Year & \multicolumn{3}{c|}{ All Workers } \\
\hline & Total & Men & Women & & Total & Men & Women \\
\hline 1937 & 96.9 & 95.8 & 99.7 & 1976 & 85.1 & 76.3 & 97.5 \\
\hline 1940 & 96.6 & 95.4 & 99.7 & 1977 & 85.2 & 76.3 & 97.5 \\
\hline 1945 & 86.3 & 78.6 & 98.9 & 1978 & 84.6 & 75.4 & 97.1 \\
\hline 1950 & 71.1 & 59.9 & 94.6 & 1979 & 90.0 & 83.6 & 98.6 \\
\hline 1951 & 75.5 & 64.6 & 96.7 & 1980 & 91.2 & 85.5 & 98.8 \\
\hline 1952 & 72.1 & 60.0 & 95.4 & 1981 & 92.4 & 87.4 & 99.0 \\
\hline 1953 & 68.8 & 55.5 & 93.8 & 1982 & 92.9 & 88.3 & 98.9 \\
\hline 1954 & 68.4 & 55.4 & 93.0 & 1983 & 93.7 & 89.6 & 99.0 \\
\hline 1955 & 74.4 & 63.4 & 95.9 & 1984 & 93.6 & 89.4 & 98.9 \\
\hline 1956 & 71.6 & 59.7 & 94.5 & 1985 & 93.5 & 89.3 & 98.8 \\
\hline 1957 & 70.1 & 58.7 & 93.1 & 1986 & 93.8 & 89.7 & 98.7 \\
\hline 1958 & 69.4 & 58.4 & 91.8 & 1987 & 93.9 & 89.9 & 98.6 \\
\hline 1959 & 73.3 & 62.7 & 94.3 & 1988 & 93.5 & 89.4 & 98.3 \\
\hline 1960 & 72.0 & 60.9 & 93.5 & 1989 & 93.8 & 90.1 & 98.3 \\
\hline 1961 & 70.8 & 59.6 & 92.4 & 1990 & 94.3 & 90.9 & 98.4 \\
\hline 1962 & 68.8 & 57.1 & 91.1 & 1991 & 94.4 & 91.1 & 98.3 \\
\hline 1963 & 67.5 & 55.5 & 90.0 & 1992 & 94.3 & 91.0 & 98.1 \\
\hline 1964 & 65.5 & 53.1 & 88.5 & 1993 & 94.4 & 91.3 & 98.1 \\
\hline 1965 & 63.9 & 51.0 & 87.3 & 1994 & 94.6 & 91.4 & 98.1 \\
\hline 1966 & 75.8 & 64.4 & 95.6 & 1995 & 94.2 & 91.0 & 97.9 \\
\hline 1967 & 73.6 & 61.5 & 94.2 & 1996 & 93.9 & 90.6 & 97.7 \\
\hline 1968 & 78.6 & 68.0 & 96.3 & 1997 & 93.8 & 90.5 & 97.6 \\
\hline 1969 & 75.5 & 62.8 & 96.0 & 1998 & 93.7 & 90.3 & 97.5 \\
\hline 1970 & 74.0 & 61.8 & 93.5 & 1999 & 93.9 & 90.7 & 97.5 \\
\hline 1971 & 71.7 & 59.1 & 91.7 & 2000 & 93.8 & 90.6 & 97.4 \\
\hline 1972 & 75.0 & 62.9 & 93.9 & 2001 & 94.1 & 91.0 & 97.5 \\
\hline 1973 & 79.7 & 68.9 & 96.2 & 2002 & 94.6 & 91.8 & 97.7 \\
\hline 1974 & 84.9 & 76.2 & 97.8 & 2003 & 94.5 & 91.8 & 97.5 \\
\hline 1975 & 84.9 & 76.4 & 97.5 & 2004 & 94.1 & 91.2 & 97.2 \\
\hline & 456 & & & & \\
\hline
\end{tabular}

Source: Annual Statistical Supplement, Table 4.B.4. 
Having considered how maximum taxable earnings related to average earnings, consider how the fractions of workers whose total earnings were above or below the annual taxable maximum have changed over time. Table 2 reports the share of the population with earnings below the taxable earnings cap. In 1937, 96.9 percent of workers had earnings below the cap, so that only 3.1 percent of workers had earnings above the cap. After rising, and reaching a third of workers in the 1960s, the fraction with earnings above the cap began to fall. By 1979, only ten percent of earners had earnings above the cap. In the following years the cap rose to the point where only five or six percent of workers had earnings above the cap. From these data, we also see that male workers are more likely than female workers to have earnings above the cap. In 1950, about forty percent of male workers and about five percent of female workers had earnings above the maximum taxable level. By 2004, 8.8 percent of men and 2.8 percent of women had earnings above the cap.

\section{Measuring the Effects on Monthly Benefits of Changes in the Social Security Earnings Cap}

To isolate the effects on benefits of changes in the cap on earnings subject to the Social Security payroll tax, the most straight forward approach is to begin with a single cohort. We choose the Early Boomer cohort of the Health and Retirement Study, ages 51 to 56 in 2004. We then use the Social Security Administration's ANYPIA program to calculate monthly benefits for this cohort. Next we impose lower earnings caps that would apply to cohorts twelve and twenty four years older. This procedure leaves earnings and the benefit formula unchanged. Benefits can then be calculated under the lower earnings cap and compared with benefits under the actual earnings cap each individual faced, while holding all other factors influencing benefits the same. 
Consider first the calculation of monthly benefits for those in the Early Boomer cohort, ages 51 to 56 in 2004. We use the Social Security earnings histories matched for members of the Early Boomer cohort, together with projections of earnings, and then compute their Social Security benefits. (As discussed below, earnings records are imputed for those who do not have a matched earnings record.)

Then to simulate the effects of the lower maximum on taxable earnings facing those from older cohorts, we simply truncate the earnings stream submitted to the ANYPIA program. For example, for covered earnings in 2004, a first calculation would use covered earnings up to the actual maximum taxable earnings in place in $2004, \$ 87,900$. If an HRS respondent had higher earnings than $\$ 87,900$, the effect of the cap on covered earnings is to reduce the earnings submitted to the benefit calculation to the amount of the cap. When simulating the effects of the lower (nominal) cap facing those born twelve years earlier, we would take the actual earnings in 2004 observed for the members of the Early Boomer cohort, but subject them to the cap on covered earnings that applied in 1992. The cap that would have applied to members of the older cohort was $\$ 55,500$. Similarly, the cap that would have faced a member of the Early Boomer cohort twenty four years earlier (than 2004) was $\$ 25,900$.

The next step is to adjust the nominal cap from twelve years earlier for the growth in wages between 1992 and 2004. We use the data from Table 1 to calculate the growth in average wage, multiplying the nominal cap in place twelve years earlier by the growth in the average annual wage over the twelve year period. A cap from the 1980s adjusted for the change in average annual wages does not differ much from the cap that applied twelve years later. But once the lower caps in place in 1970 enter into the calculation, there is a substantial effect of the change in the earnings cap on benefits. 
Table 3: Estimates of AIME and PIA with Caps Experienced by 2004, 1992 and 1980 Cohorts, for Individuals Ages 51-56 in 2004

\begin{tabular}{|l|c|c|c|c|c|c|}
\hline \multirow{3}{*}{ Households } & \multicolumn{2}{|c|}{ 2004 Caps } & \multicolumn{2}{|c|}{ Adjusted 1992 Caps } & \multicolumn{2}{|c|}{ Adjusted 1980 Caps } \\
\cline { 2 - 7 } & AIME & $\begin{array}{c}\text { PIA at } \\
\text { NR age }\end{array}$ & AIME & $\begin{array}{c}\text { PIA at } \\
\text { NR age }\end{array}$ & AIME & $\begin{array}{c}\text { PIA at } \\
\text { NR age }\end{array}$ \\
\hline \hline \multirow{2}{*}{ All Rs** } & $\begin{array}{c}2825 \\
(2223)^{* * *}\end{array}$ & $\begin{array}{c}1432 \\
(719)\end{array}$ & $\begin{array}{c}2724 \\
(2065)\end{array}$ & $\begin{array}{c}1410 \\
(694)\end{array}$ & $\begin{array}{c}2576 \\
(1806)\end{array}$ & $\begin{array}{c}1380 \\
(652)\end{array}$ \\
\hline \multirow{2}{*}{ Males } & 3378 & 1606 & $\begin{array}{c}3200 \\
(745)\end{array}$ & $\begin{array}{c}1568 \\
(710)\end{array}$ & $\begin{array}{c}2982 \\
(1892)\end{array}$ & $\begin{array}{c}1524 \\
(656)\end{array}$ \\
\hline \multirow{2}{*}{ Females } & $\begin{array}{c}2372 \\
(1917)\end{array}$ & $\begin{array}{c}1289 \\
(664)\end{array}$ & $\begin{array}{c}2333 \\
(1843)\end{array}$ & $\begin{array}{c}1280 \\
(653)\end{array}$ & $\begin{array}{c}2243 \\
(1660)\end{array}$ & $\begin{array}{c}1261 \\
(624)\end{array}$ \\
\hline
\end{tabular}

* AIME is average indexed monthly earnings. PIA is primary insurance amount. NR age is normal retirement age.

** The number of observations with either a matched or imputed earnings record who are insured is 2,476. There are 1,116 males, and 1,360 females.

*** Standard deviations are in parentheses.

Note: Quarters of coverage are reported in the Social Security record. After 2005, when earnings are projected, quarters of coverage are based on the relationship between total annual covered earnings and the amount of earnings needed to earn one quarter of coverage. 
One other adjustment we make is to impute benefits for those without a matched Social Security earnings history. We use a nearest neighbor approach. A regression is run for those who have a matched earnings record, where the Primary Insurance Amount computed from the earnings record is the dependent variable. Independent variables are taken from the respondent reports to the HRS. ${ }^{8}$ The nearest neighbor is then selected on the basis of the predicted PIA, including in the sample both those with and without matched earnings records. We then replace the missing record with the entire Social Security record of the donor and treat the observation for which a value was imputed as if the earnings record had never been missing.

From Table 3, row 1, columns 1 and 3, Average Indexed Monthly Earnings are increased by about 3.7 percent $(2825 / 2724)$ when the payroll tax cap that applied to the Early Boomer cohort is used instead of the cap that applied to the HRS cohort, whose members were twelve years older. Given the progressivity of the benefit formula, the primary insurance amount is only $1.6(1432 / 1410)$ percent greater when the cap from 2004 (row 1, column 2) is used instead of the adjusted cap that applied to the 1992 cohort (row 1, column 4). For men, the difference in AIME is 5.6 percent (3378/3200), wider than the difference for women of 1.7 percent $(2372 / 2333)$. As expected, women are much less likely to have earnings near the cap, and thus are much less likely to be affected by an increase in the cap. The corresponding effects on benefits of raising the earnings cap between the HRS and Early Boomer cohorts are 2.4 percent (1606/1568) for men, and 0.7 percent $(1289 / 1280)$ for women.

\footnotetext{
${ }^{8}$ Covariates used in imputing earnings records from respondent reports to the HRS include: annual earnings from current job, household income from last calendar year, demographic characteristics, indicators of marital status and history, age, work history, including reported work in each HRS wave, tenure on longest and current job, total number of years worked, number of jobs, number of jobs worked five or more years, industry and occupation from current job, union membership, whether public employee, if U.S. born, home ownership, number of children, if the individual is insured for benefits at normal retirement age, labor force and disability status, self employment status in 2004, and veteran's status.
} 
The last two columns of Table 3 make the analogous calculations regarding the increase in the real earnings cap over twenty four years, allowing us to compare the effects of the real caps in place for those members of the Early Boomer cohort who were 51 to 56 in 2004, with the real caps for those members of the Children of the Depression (CODA) cohort who were 51 to 56 in 1980. Over the entire population, the difference in benefits generated by raising the maximum level of earnings subject to the payroll tax is a much more substantial $3.8(1432 / 1380)$ percent. For men, there is a 5.4 percent $(1606 / 1524)$ increase in benefits from raising the earnings cap between the Early Boomer and CODA cohorts. For women, the difference is 2.2 percent $(1289 / 1261)$.

Table 4 presents the analogous results after sorting the population by AIME quartile. Tables 5, and 6 present the same results by AIME quartile separately for men and women. 
Table 4: Average PIA at Normal Retirement Age by AIME Quartiles for Individuals Ages 51-56 in 2004, with 2004, 1992 and 1980 Caps

\begin{tabular}{|l|c|c|c|c|c||}
\hline $\begin{array}{l}\text { AIME } \\
\text { Fuartiles } 2004 \text { caps }\end{array}$ & 2004 Caps & $\begin{array}{c}\text { Adjusted } \\
1992 \text { Caps }\end{array}$ & $\begin{array}{c}\text { Adjusted } \\
1980 \\
\text { Caps }\end{array}$ & $\begin{array}{c}\text { Adjusted } \\
\text { Growth } \\
\text { Rate from } \\
1992 \\
\text { Caps to } \\
2004 \\
\text { Caps }\end{array}$ & $\begin{array}{c}\text { Adjusted } \\
\text { Growth } \\
\text { Rate from } \\
1980 \text { Caps } \\
\text { to 2004 } \\
\text { Caps }\end{array}$ \\
\hline \hline $\begin{array}{l}\text { First } \\
\text { Quartile }\end{array}$ & 610 & 608 & 608 & $0 \%$ & $0 \%$ \\
\hline Second Quartile & 1087 & 1082 & 1081 & $0 \%$ & $1 \%$ \\
\hline Third Quartile & 1582 & 1566 & 1553 & $1 \%$ & $2 \%$ \\
\hline Fourth Quartile & 2452 & 2386 & 2278 & $3 \%$ & $8 \%$ \\
\hline
\end{tabular}


Table 5: Average PIA at Normal Retirement Age by AIME Quartiles for Males Ages 51-56 in 2004, with 2004, 1992 and 1980 Caps

\begin{tabular}{|l|c|c|c|c|c|}
\hline $\begin{array}{l}\text { AIME } \\
\text { Quartiles } \\
\text { From 2004 } \\
\text { caps }\end{array}$ & 2004 Caps & $\begin{array}{c}\text { Adjusted } \\
1992 \text { Caps }\end{array}$ & $\begin{array}{c}\text { Adjusted } \\
1980 \\
\text { Caps }\end{array}$ & $\begin{array}{c}\text { Growth } \\
\text { Rate from } \\
\text { Adjusted } \\
1992 \\
\text { Caps to } \\
2004 \\
\text { Caps }\end{array}$ & $\begin{array}{c}\text { Growth } \\
\text { Rate from } \\
\text { Adjusted } \\
1980 \text { Caps } \\
\text { to 2004 } \\
\text { Caps }\end{array}$ \\
\hline $\begin{array}{l}\text { First } \\
\text { Quartile }\end{array}$ & 732 & 730 & 730 & $0 \%$ & $0 \%$ \\
\hline $\begin{array}{l}\text { Second } \\
\text { Quartile }\end{array}$ & 1230 & 1215 & 1213 & $1 \%$ & $1 \%$ \\
\hline $\begin{array}{l}\text { Third } \\
\text { Quartile }\end{array}$ & 1840 & 1800 & 1771 & $2 \%$ & $4 \%$ \\
\hline $\begin{array}{l}\text { Fourth } \\
\text { Quartile }\end{array}$ & 2632 & 2535 & 2389 & $4 \%$ & $10 \%$ \\
\hline
\end{tabular}


Table 6: Average PIA at Normal Retirement Age by AIME Quartiles for Females Ages 51-56 in 2004, with 2004 and 1992, 1980 Caps

\begin{tabular}{|l|c|c|c|c|c|}
\hline $\begin{array}{l}\text { AIME } \\
\text { Quartiles } \\
\text { From 2004 } \\
\text { caps }\end{array}$ & 2004 Caps & $\begin{array}{c}\text { Adjusted } \\
1992 \text { Caps }\end{array}$ & $\begin{array}{c}\text { Adjusted } \\
1980 \\
\text { Caps }\end{array}$ & $\begin{array}{c}\text { Growth } \\
\text { Rate from } \\
\text { Adjusted } \\
1992 \\
\text { Caps to } \\
2004 \\
\text { Caps }\end{array}$ & $\begin{array}{c}\text { Growth } \\
\text { Rate from } \\
\text { Adjusted } \\
1980 \text { Caps } \\
\text { to 2004 } \\
\text { Caps }\end{array}$ \\
\hline $\begin{array}{l}\text { First } \\
\text { Quartile }\end{array}$ & 529 & 527 & 527 & $0 \%$ & $0 \%$ \\
\hline $\begin{array}{l}\text { Second } \\
\text { Quartile }\end{array}$ & 1001 & 999 & 997 & $0 \%$ & $0 \%$ \\
\hline $\begin{array}{l}\text { Third } \\
\text { Quartile }\end{array}$ & 1413 & 1407 & 1401 & $0 \%$ & $1 \%$ \\
\hline $\begin{array}{l}\text { Fourth } \\
\text { Quartile }\end{array}$ & 2218 & 2191 & 2123 & $1 \%$ & $4 \%$ \\
\hline
\end{tabular}


We focus on columns 4 and 5 of each of these tables, which calculate ratios based on the data in the first three columns. From the first row of Table 4, columns 4 and 5, for those in the bottom quartile of the AIME distribution, there is no effect on the Primary Insurance Amount from raising the cap between the HRS and either the Early Boomer or Children of the Depression cohorts. Benefits are increased by 0 and 1 percent for those in the second quartile, and 1 and 2 percent for those in the third quartile. As expected, there are much larger effects from changing the caps for those in the fourth AIME quartile, bottom row of Table 4. If those in the upper quartile of the AIME distribution in 2004 were subject to the real caps imposed on those twelve years older, their primary insurance amount would be roughly 3 percent lower. Compared to the real cap on earnings that would have obtained for a cohort 51 to 56 in 1980, using the cap from 2004 increases the benefits of those in the fourth AIME quartile by 8 percent.

Comparing Tables 5 with 6 , the effects of raising the caps are much larger for men than for women. For example, comparing those in the top quartile of men and women, focusing on the change created by raising the cap from the level that applied to those 51 to 56 in 1992 to the cap from 2004, benefits for men increase by 4 percent, while women's benefits increase only by 1 percent (bottom row, column 4 of each table). Focusing on the difference in the caps that applied to those in the Early Boomer and CODA cohorts, the increase in the cap from 1980 to 2004 increases benefits for men in the top quartile by 10 percent, while increasing the benefits of women in the top quartile by 4 percent.

\section{Effects of Changes in Maximum Earnings Subject to the Payroll Tax on Taxes and Benefits for Those Whose Earnings Are at or Above the Maximum.}


Next we would like to see how past increases in maximum earnings subject to the payroll tax affected the present values of both tax and benefit streams for those with maximum earnings. For purposes of example, we begin by examining the effects of changes in the earnings maximum over time for a man from the Early Boomer cohort who represents a person with maximum covered earnings. This man was born in 1948 and survived at least to age 56 in 2004 . He began working in 1969 at age 21, and if he survived until 2009, stopped working after 2009 at age 61 . He will claim benefits at age 66 in 2014. We first assume that each year's earnings are at the maximum covered by the payroll tax throughout his work history. Thus from Table 1, in 2004 his earnings are $\$ 87,900$; in 2003 they are $\$ 87,000$, etc.

Two things should be noted about the tax rates we use. First we use only the OASI tax rates paid by respondents and their employers. Because we do not include disability payments as part of benefits, (in our work below with HRS data, we do not model participation in the DI program), we also ignore disability benefits. Second, the tax rates have been changing over time. Thus the payroll tax rates paid in earlier years of work differ from those charged later on. (See Social Security Administration, 2007, Table 2.A3). ${ }^{9}$

Next we impose the caps on earnings that would have applied had this individual been twelve years older, born in 1936. However, while the cap is determined as if he were born twelve years earlier, his actual earnings are taken to be those described above, equal to the caps experienced throughout his working life for a person born in 1948. Thus in 2004 his earnings are $\$ 87,900$, but the payroll tax is capped at the level from twelve years earlier, in 1992, so that only $\$ 55,500$ of those earnings are subject to the payroll tax. In 2003 , of his $\$ 87,000$ in earnings,

\footnotetext{
${ }^{9}$ Note we hold the tax rates constant between cohorts, allowing only the ceiling on taxable earnings to change from one cohort to the next.
} 
$\$ 53,400$, the earnings cap in 1991 , is subject to the payroll tax. We then adjust the earnings caps from the remaining years as if he were born twelve years earlier.

The earnings caps are stated in nominal terms. To adjust the caps from twelve years earlier to real terms, once again caps on earnings from twelve years earlier are increased by the growth in wages. For example, the growth in wages is 55.4 percent $(35,649 / 22,935)$ between 1992 and 2004; and 56.2 percent $(34,065 / 21,812)$ between 1991 and 2003, and so on.

Once we complete the analysis of the effect of imposing the earnings caps that would have applied to a man twelve years older, we repeat the calculation for an individual who is twenty four years older. Thus we impose the caps that would have applied to a person born in 1924, but otherwise leave earnings at the level of the caps that applied to a person born in 1948, and keep all other factors the same.

The first thing to notice in Table 7 is how poor a deal Social Security is for a person with earnings at or above the cap. The present value of the basic benefit in 2004 is $\$ 226,462$, while the present value of taxes paid is $\$ 454,894$. As we know, the benefit formula is designed to redistribute benefits among those with different levels of earnings. The replacement rates specified by the formula determining Social Security benefits in 2004 decline from 90 percent of the first $\$ 7,344$ of annual earnings, to 32 percent of the next $\$ 36,924$, down to 15 percent of any remaining earnings through the covered maximum. Nevertheless, the relation between benefits and taxes is better than indicated in the table. The deal faced by our representative individual would be greatly improved by counting spouse and survivor benefits, which are more important for those with higher earnings (Gustman and Steinmeier, 2001).

Nevertheless, increasing the earnings cap does raise benefits and taxes. The remainder of the data in Table 7 tells us just how much benefits and taxes were increased for this high earner 
as the ceiling on covered earnings was raised to the level that applied to a person born in 1948 from a person born in 1936, twelve years earlier, and then from a person born in 1924, 24 years earlier. After adjusting the cap in real terms, from columns 1 and 2, the present value of benefits increase due to the increase in the payroll tax cap over the twelve years from $\$ 207,301$ to $\$ 226,462$, or 9.2 percent. The present value of payroll taxes paid increase much more, from $\$ 358,836$ to $\$ 454,894$, or by 26.8 percent. Comparing columns 1 and 3 , which report comparable figures over twenty four years, the present value of benefits increase due to the increase in the cap on earnings subject to the payroll tax from $\$ 198,340$ to $\$ 226,462$, or 14.2 percent. The present value of payroll taxes paid increase from $\$ 335,758$ to $\$ 454,894$, or by 35.5 percent. A number of interest for policy is the leakage in benefits created by the increase in the payroll tax cap. This number indicates the share of the tax increase that is used to support higher benefits. Comparing first the Early Boomer and HRS cohorts, the change in the present value of benefits divided by the change in the present value of taxes from raising the ceiling on the payroll tax amounts to about 20 percent, as reported in column 4 of Table 7. Between the CODA and Early Boomer cohorts, from the last column in the table, the change in the present value of benefits divided by the change in the present value of taxes from raising the ceiling on the payroll tax, after adjusting the change in the caps for changes in the wage, amounts to about 24 percent.

Thus our example suggests that for a person earning at the maximum level covered by Social Security, about a fifth of the additional taxes collected due to the increase in the earnings cap are used to pay for increased benefits, reducing the incremental funds available for addressing the Social Security revenue shortfall by about a fifth. When we use HRS data, the share of increased taxes that leaks back in the form of additional benefits will be about a quarter. 
Table 7: Estimates of Present Values of Social Security Benefits and Taxes with 2004, 1992 and 1980 Caps for an Individual with Maximum Covered Earnings, and Ratios of Changes in Benefits Over Changes in Taxes: Age 56 in 2004

\begin{tabular}{|c|c|c|c|c|c|}
\hline Present Values & 2004 Caps & $\begin{array}{l}\text { Adjusted } \\
1992 \text { Caps }\end{array}$ & $\begin{array}{l}\text { Adjusted } \\
1980 \text { Caps }\end{array}$ & $\begin{array}{l}2004 \text { Caps } \\
\text { to Adjusted } \\
1992 \text { Caps, } \\
\text { Ratio of } \\
\text { Changes in } \\
\text { Benefits } \\
\text { Over } \\
\text { Changes in } \\
\text { Taxes } \\
\end{array}$ & $\begin{array}{l}\text { 2004 Caps } \\
\text { to Adjusted } \\
1980 \text { Caps, } \\
\text { Ratio of } \\
\text { Changes in } \\
\text { Benefits } \\
\text { Over } \\
\text { Changes in } \\
\text { Taxes } \\
\end{array}$ \\
\hline $\begin{array}{l}\text { Social Security } \\
\text { Benefits }\end{array}$ & 226,462 & 207,301 & 198,340 & \multirow{2}{*}{0.20} & \multirow{2}{*}{0.24} \\
\hline $\begin{array}{l}\text { Social Security } \\
\text { Taxes }\end{array}$ & 454,894 & 358,836 & 335,758 & & \\
\hline
\end{tabular}

Note:

1- Uses real interest rate when computing discounted present value of benefits as of normal retirement age.

2- Uses nominal interest rate when discounting that benefit from normal retirement age to 2004 .

3- Uses nominal interest rate for calculating the present value of taxes paid up to 2004.

4- Uses nominal interest rate for discounting taxes paid after 2004 back to 2004.

5 - Uses $2 *$ OASI tax rates for individuals in calculating total taxes paid. 


\section{Effects of Changes in Maximum Earnings Subject to the Payroll Tax on Benefits and Taxes for the Early Boomer Cohort}

Now we turn to the data from the HRS and apply those data as we did in Section III, here accounting for the effects of changes in the ceiling on covered earnings on both benefits and taxes. Our baseline is the Early Boomer cohort. In examining the effect of changes in the ceiling on taxable earnings, we once again ask how benefits and taxes would change if we change only the maximum earnings subject to the payroll tax, holding earnings and other aspects of the tax and benefit rules, such as the payroll tax rate, constant between the Early Boomer cohort and older cohorts.

Table 8 follows the format of the tables in the previous section. Comparing the effects of the earnings caps that applied to the Early Boomer cohort and the HRS cohort twelve years older, we see from columns 1 and 2 that the present value of benefits is increased by 1.5 percent $(120,991 / 119,190)$ due to the higher cap applying to the members of the early boomer cohort. Taxes are increased by 5.3 percent $(141,637 / 134,547)$. So the increase in benefits from the higher cap on covered payroll amounts to 25.4 percent of the increase in taxes, $(120,991$ $119,190) /(141,637-134,547)$. 
Table 8: Estimates of Present Values of Social Security Benefits and Taxes with 2004, 1992 and 1980 Caps For All Individuals, Including Imputations: Ages 51-56 in 2004

\begin{tabular}{|l|c|c|c|c|c||}
\hline Present Values & 2004 Caps & $\begin{array}{c}\text { Adjusted } \\
1992 \text { Caps }\end{array}$ & $\begin{array}{c}\text { Adjusted } \\
1980 \text { Caps }\end{array}$ & $\begin{array}{c}\text { 2004 Caps } \\
\text { to Adjusted } \\
\text { 1992 Caps, } \\
\text { Ratio of } \\
\text { Changes in } \\
\text { Benefits } \\
\text { Over } \\
\text { Changes in } \\
\text { Taxes }\end{array}$ & $\begin{array}{c}\text { 2004 Caps } \\
\text { to Adjusted } \\
\text { 1980 Caps, } \\
\text { Ratio of } \\
\text { Changes in } \\
\text { Benefits } \\
\text { Over } \\
\text { Changes in } \\
\text { Taxes }\end{array}$ \\
\hline $\begin{array}{l}\text { Social Security } \\
\text { Benefits }\end{array}$ & $\begin{array}{c}120,991 \\
(58,005)^{*}\end{array}$ & $\begin{array}{c}119,190 \\
(56,140)\end{array}$ & $\begin{array}{c}116,730 \\
(52,839)\end{array}$ & \\
\hline $\begin{array}{l}\text { Social Security } \\
\text { Taxes }\end{array}$ & $\begin{array}{c}141,637 \\
(112,212)\end{array}$ & $\begin{array}{c}134,547 \\
(99,837)\end{array}$ & $\begin{array}{c}127,964 \\
(88,819)\end{array}$ & \\
\hline
\end{tabular}

Note: Respondents who are insured for benefits at normal retirement age are included. Number of observations is 2,475 . The sample includes respondents with matched Social Security records. Records are imputed for those with missing records. Social Security benefits are the present value of benefits at normal retirement age discounted to 2004 dollars. Social Security taxes are the present value of taxes paid up to the year prior to the entitlement year, in 2004 dollars. Present values of benefits and taxes are not weighted. Weighted averages are similar to un-weighted.

*standard deviation 
Comparable figures for the differences created by the caps experienced by the Early Boomer and Children of the Depression cohort, in columns 3 and 1, suggest that the effect of the increase in the payroll tax ceiling over twenty four years was to raise benefits by 3.7 percent $(120,991 / 116,730)$, while raising taxes by 10.7 percent $(141,637 / 127,964)$. Thus the leakage from taxes to benefits amounted to 31.2 percent $[(120,991-116,730) /(141,637-127,964)]$ of the increase in taxes received.

The Appendix contains four tables that decompose the benefit and tax changes first between men and women (Table 9), then by quartile (Table 10). As expected, these tables show that the changes in benefits and taxes were concentrated, but not exclusively located, in the top quartiles, and were much larger for men than for women. Tables 11 and 12, further disaggregate the results, focusing on the distributions within quartiles of men and women, and the changes in benefits and taxes within quartile, by gender.

There are two basic findings from these results. First, as expected, most of the increases in taxes and benefits are concentrated in the men who fall in the top quartile of earners. As seen in Table 11, bottom row, their taxes are increased by 12.7 percent $(354,136 / 314,276)$ over the taxes of those in a cohort twelve years older, and by 26.7 percent $(354,136 / 279,625)$ relative to the taxes of those who are twenty four years older. The comparable increases for their benefits, shown in row 7, are 3.9 percent $(196,633 / 189,273)$ and 10.2 percent $(196,633 / 178,393)$. Overall, the ratio of the increase in benefits to the increase in taxes for men falling in the top quartile of earners is 18 percent and 24 percent compared to those in cohorts twelve and twenty four years older.

Increases in the ceiling on covered earnings also affects the taxes and benefits of men in the third quartile, but the effect is much smaller than it is for members of the top quartile of 
earners. For example, for men in the fourth quartile, between the 1980 and 2004 caps, taxes increase by almost $\$ 74,500$, while for members of the third quartile, taxes increase by only $\$ 11,700$.

Similarly, benefits and taxes reported in Table 12 are seen to be increased for women in the top quartile of female earners as a result of the increase in the ceiling on earnings covered by the payroll tax. But the taxes paid by women in the top quartile increase by only $\$ 23,600$ $(242,402-218,791)$ as a result of the increase in the payroll tax ceiling over 24 years.

\section{Conclusions:}

This paper has analyzed how changes in the level of maximum earnings subject to the Social Security payroll tax have affected Social Security benefits and taxes paid. For those in the Early Boomer cohort of the Health and Retirement Study, ages 51 to 56 in 2004, benefits increased by 1.5 percent due to the increase in the real payroll tax ceiling compared to the cohort twelve years older, and by 3.7 percent compared to the cohort twenty four years older. Tax receipts increased by 5.3 and 10.7 percent over tax receipts that would have been collected under the tax ceilings that applied to the cohorts 12 and 24 years older respectively. Thus about 25 percent of the additional tax revenues created by increasing the payroll tax cap between the Early Boomer cohort and those twelve years older is used to increase benefits. Similarly, about 31 percent of the additional tax revenues created by the increase in the payroll tax cap between the Early Boomer cohort and those twenty four years older is used to increase benefits.

There are two important difference between the effect of raising a given amount of tax dollars by increasing the payroll tax rate, as compared to increasing the maximum earnings subject to the payroll tax. First, because increasing the maximum income subject to the payroll 
tax increases both tax revenues and benefit payments, an increase in the ceiling on income subject to the payroll tax that generates the same addition to taxes as does an increase in the payroll tax rate, nevertheless generates less net revenue. Second, since both the tax increase and benefit increase from raising the ceiling on earnings subject to the payroll tax apply mainly to those in the top income brackets, there are distributional differences. In particular, only high earners face a tax increase, only high earners receive a benefit increase, and the tax increase is three to four times the size of the benefit increase. 


\section{References}

Gustman, Alan L. and Thomas L. Steinmeier. 2001. "How Effective Is Redistribution Under The Social Security Benefit Formula?” Journal of Public Economics 82(1): 1-28.

Gustman, Alan L., Nahid Tabatabai and Thomas L. Steinmeier. 2010. "What the Stock Market Decline Means for the Financial Security and Retirement Choices of the NearRetirement Population". Journal of Economic Perspectives 24(1): 161-182.

Social Security Administration. 2007. Annual Statistical Supplement of the Social Security Bulletin, 2007. U.S. Government Printing Office.

United States Senate, Special Committee on Aging. 2010. "Social Security Modernization: Options to Address Solvency and Benefit Adequacy". Washington, D.C.: U.S. Government Printing Office, May. 


\section{Appendix}

Table 9: Estimates of Present Values of Social Security Benefits and Taxes at Normal Retirement Age with Caps for 2004, 1992 and 1980 Cohorts, All Individuals by Sex, Including Imputations: Ages 51-56 in 2004

\begin{tabular}{|c|c|c|c|c|c|}
\hline Present Values & 2004 Caps & $\begin{array}{c}\text { Adjusted } \\
1992 \text { Caps }\end{array}$ & $\begin{array}{l}\text { Adjusted } \\
1980 \text { Caps }\end{array}$ & $\begin{array}{c}2004 \text { Caps } \\
\text { to } \\
\text { Adjusted } \\
1992 \text { Caps, } \\
\text { Ratio of } \\
\text { Changes in } \\
\text { Benefits } \\
\text { Over } \\
\text { Changes in } \\
\text { Taxes }\end{array}$ & $\begin{array}{c}2004 \text { Caps } \\
\text { to Adjusted } \\
1980 \text { Caps, } \\
\text { Ratio of } \\
\text { Changes in } \\
\text { Benefits } \\
\text { Over } \\
\text { Changes in } \\
\text { Taxes }\end{array}$ \\
\hline \multicolumn{6}{|l|}{ All } \\
\hline Benefits & $\begin{array}{c}120,991 \\
(58,005)^{*}\end{array}$ & $\begin{array}{l}119,190 \\
(56,140)\end{array}$ & $\begin{array}{l}116,730 \\
(52,839)\end{array}$ & \multirow[t]{2}{*}{.25} & \multirow[t]{2}{*}{.31} \\
\hline Taxes & $\begin{array}{c}141,637 \\
(112,212)\end{array}$ & $\begin{array}{l}134,547 \\
(99,837)\end{array}$ & $\begin{array}{l}127,964 \\
(88,819)\end{array}$ & & \\
\hline \multicolumn{6}{|l|}{ Males } \\
\hline Benefits & $\begin{array}{l}122,450 \\
(54,979)\end{array}$ & $\begin{array}{l}119,516 \\
(52,161)\end{array}$ & $\begin{array}{l}116,207 \\
(48,133)\end{array}$ & \multirow[t]{2}{*}{.23} & \multirow[t]{2}{*}{.28} \\
\hline Taxes & $\begin{array}{c}175,460 \\
(124,641)\end{array}$ & $\begin{array}{c}162,876 \\
(107,366)\end{array}$ & $\begin{array}{l}153,141 \\
(93,668)\end{array}$ & & \\
\hline \multicolumn{6}{|l|}{ Females } \\
\hline Benefits & $\begin{array}{l}119,779 \\
(60,350)\end{array}$ & $\begin{array}{l}118,922 \\
(59,233)\end{array}$ & $\begin{array}{l}117,159 \\
(56,424)\end{array}$ & \multirow[t]{2}{*}{.33} & \multirow[t]{2}{*}{.39} \\
\hline Taxes & $\begin{array}{l}113,882 \\
(92,061)\end{array}$ & $\begin{array}{l}111,299 \\
(86,574)\end{array}$ & $\begin{array}{l}107,158 \\
(78,874)\end{array}$ & & \\
\hline
\end{tabular}

*Standard deviation. 
Table 10: Averages of Present Values of Social Security Benefits and Taxes at Normal Retirement Age by AIME Quartiles for Respondents Ages 51-56 in 2004 with Caps for 2004, 1992 and 1980 Cohorts

\begin{tabular}{|c|c|c|c|c|c|}
\hline $\begin{array}{l}\text { AIME } \\
\text { Quartiles } \\
\text { From } 2004 \text { caps }\end{array}$ & 2004 Caps & $\begin{array}{l}\text { Adjusted } \\
1992 \text { Caps }\end{array}$ & $\begin{array}{l}\text { Adjusted } \\
1980 \text { Caps }\end{array}$ & $\begin{array}{c}2004 \text { Caps } \\
\text { to Adjusted } \\
1992 \text { Caps, } \\
\text { Ratio of } \\
\text { Changes in } \\
\text { Benefits } \\
\text { Over } \\
\text { Changes in } \\
\text { Taxes }\end{array}$ & $\begin{array}{c}2004 \text { Caps } \\
\text { to Adjusted } \\
1980 \text { Caps, } \\
\text { Ratio of } \\
\text { Changes in } \\
\text { Benefits } \\
\text { Over } \\
\text { Changes in } \\
\text { Taxes }\end{array}$ \\
\hline \multicolumn{6}{|l|}{ First Quartile } \\
\hline Benefits & 54,539 & 54,424 & 54,434 & \multirow{2}{*}{ * } & \multirow{2}{*}{$*$} \\
\hline Taxes & 32,702 & 32,603 & 32,611 & & \\
\hline \multicolumn{6}{|l|}{ Second Quartile } \\
\hline Benefits & 94,473 & 94,022 & 93,974 & \multirow{2}{*}{.44} & \multirow{2}{*}{.49} \\
\hline Taxes & 80,644 & 79,617 & 79,625 & & \\
\hline \multicolumn{6}{|l|}{ Third Quartile } \\
\hline Benefits & 136,231 & 134,939 & 133,802 & \multirow{2}{*}{.46} & \multirow{2}{*}{.52} \\
\hline Taxes & 151,333 & 148,518 & 146,617 & & \\
\hline \multicolumn{6}{|l|}{ Fourth Quartile } \\
\hline Benefits & 198,873 & 193,565 & 184,901 & \multirow{2}{*}{.22} & \multirow{2}{*}{.29} \\
\hline Taxes & 302,101 & 277,676 & 253,230 & & \\
\hline
\end{tabular}

*Ratios of differences only reported when both tax and benefit changes exceed $\$ 1,000$. 
Table 11: Average Present Value Social Security Benefits and Taxes at Normal Retirement Age by AIME Quartiles for Males Ages 51-56 in 2004 with Caps for 2004, 1992 and 1980 Cohorts

\begin{tabular}{|c|c|c|c|c|c|}
\hline $\begin{array}{l}\text { AIME } \\
\text { Quartiles } \\
\text { From } 2004 \text { caps }\end{array}$ & 2004 Caps & $\begin{array}{l}\text { Adjusted } \\
1992 \text { Caps }\end{array}$ & $\begin{array}{l}\text { Adjusted } \\
1980 \text { Caps }\end{array}$ & $\begin{array}{l}2004 \text { Caps } \\
\text { to Adjusted } \\
1992 \text { Caps, } \\
\text { Ratio of } \\
\text { Changes in } \\
\text { Benefits } \\
\text { Over } \\
\text { Changes in } \\
\text { Taxes }\end{array}$ & $\begin{array}{c}2004 \text { Caps } \\
\text { to Adjusted } \\
1980 \text { Caps, } \\
\text { Ratio of } \\
\text { Changes in } \\
\text { Benefits } \\
\text { Over } \\
\text { Changes in } \\
\text { Taxes }\end{array}$ \\
\hline \multicolumn{6}{|l|}{ First Quartile } \\
\hline Benefits & 57,348 & 57,195 & 57,229 & \multirow{2}{*}{$*$} & \multirow{2}{*}{$*$} \\
\hline Taxes & 46,261 & 45,963 & 46,028 & & \\
\hline \multicolumn{6}{|l|}{ Second Quartile } \\
\hline Benefits & 95,525 & 94,402 & 94,243 & \multirow{2}{*}{.42} & \multirow{2}{*}{.45} \\
\hline Taxes & 105,246 & 102,580 & 102,394 & & \\
\hline \multicolumn{6}{|l|}{ Third Quartile } \\
\hline Benefits & 140,958 & 137,858 & 135,627 & \multirow{2}{*}{.41} & \multirow{2}{*}{.45} \\
\hline Taxes & 197,254 & 189,702 & 185,526 & & \\
\hline \multicolumn{6}{|l|}{ Fourth Quartile } \\
\hline Benefits & 196,633 & 189,273 & 178,393 & \multirow{2}{*}{.18} & \multirow{2}{*}{.24} \\
\hline Taxes & 354,136 & 314,276 & 279,625 & & \\
\hline
\end{tabular}

*Ratios of differences only reported when both tax and benefit change exceed $\$ 1,000$. 
Table 12: Average Present Values of Social Security Benefits and Taxes at Normal Retirement Age by AIME Quartiles for Females Ages 51-56 in 2004 with Caps for 2004, 1992 and 1980 Cohorts

\begin{tabular}{|c|c|c|c|c|c|}
\hline $\begin{array}{l}\text { AIME } \\
\text { Quartiles } \\
\text { From } 2004 \text { caps }\end{array}$ & 2004 Caps & $\begin{array}{l}\text { Adjusted } \\
1992 \text { Caps }\end{array}$ & $\begin{array}{l}\text { Adjusted } \\
1980 \text { Caps }\end{array}$ & $\begin{array}{c}2004 \text { Caps } \\
\text { to Adjusted } \\
1992 \text { Caps, } \\
\text { Ratio of } \\
\text { Changes in } \\
\text { Benefits } \\
\text { Over } \\
\text { Changes in } \\
\text { Taxes } \\
\end{array}$ & $\begin{array}{c}2004 \text { Caps } \\
\text { to Adjusted } \\
1980 \text { Caps, } \\
\text { Ratio of } \\
\text { Changes in } \\
\text { Benefits } \\
\text { Over } \\
\text { Changes in } \\
\text { Taxes } \\
\end{array}$ \\
\hline \multicolumn{6}{|l|}{ First Quartile } \\
\hline Benefits & 50,732 & 50,575 & 50,591 & \multirow{2}{*}{ * } & \multirow{2}{*}{$*$} \\
\hline Taxes & 26,842 & 26,728 & 26,747 & & \\
\hline \multicolumn{6}{|l|}{ Second Quartile } \\
\hline Benefits & 93,172 & 92,964 & 92,821 & \multirow{2}{*}{$*$} & \multirow{2}{*}{$*$} \\
\hline Taxes & 63,475 & 63,087 & 62,879 & & \\
\hline \multicolumn{6}{|l|}{ Third Quartile } \\
\hline Benefits & 131,427 & 130,892 & 130,257 & \multirow{2}{*}{ * } & \multirow{2}{*}{.58} \\
\hline Taxes & 123,024 & 122,002 & 121,010 & & \\
\hline \multicolumn{6}{|l|}{ Fourth Quartile } \\
\hline Benefits & 204,036 & 201,505 & 195,214 & \multirow{2}{*}{.29} & \multirow{2}{*}{.37} \\
\hline Taxes & 242,402 & 233,594 & 218,791 & & \\
\hline
\end{tabular}

*Ratios of differences are only reported when both tax and benefit changes exceed $\$ 1,000$. 